\title{
Notch and breast cancer metastasis: Current knowledge, new sights and targeted therapy (Review)
}

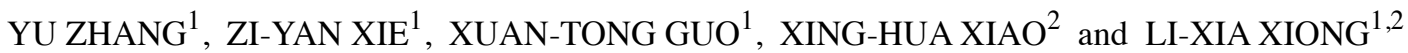 \\ ${ }^{1}$ Department of Pathophysiology, Medical College, Nanchang University; ${ }^{2}$ Jiangxi Province Key Laboratory of \\ Tumor Pathogenesis and Molecular Pathology, Nanchang University, Nanchang, Jiangxi 330006, P.R. China
}

Received October 31, 2018; Accepted June 21, 2019

DOI: $10.3892 / \mathrm{ol} .2019 .10653$

\begin{abstract}
Breast cancer is the most common type of invasive cancer in females and metastasis is one of the major causes of breast cancer-associated mortality. Following detachment from the primary site, disseminated tumor cells (DTCs) enter the bloodstream and establish secondary colonies during the metastatic process. An increasing amount of studies have elucidated the importance of Notch signaling in breast cancer metastasis; therefore, the present review focuses on the mechanisms by which Notch contributes to the occurrence of breast cancer DTCs, increases their motility, establishes interactions with the tumor microenvironment, protects DTCs from host surveillance and finally facilitates secondary colonization. Identification of the underlying mechanisms of Notch-associated breast cancer metastasis will provide additional insights that may contribute towards the development of novel Notch-targeted therapeutic strategies, which may aid in reducing metastasis, culminating in an improved patient prognosis.
\end{abstract}

\section{Contents}

1. Introduction

2. Notch signaling

3. Notch and biased cell fate determinants

4. Notch and local invasion

5. Notch and survival in circulation

6. Notch and secondary colonization

7. Notch-associated microRNAs in breast cancer metastasis

8. Application of Notch signaling in the clinical treatment of breast cancer

9. Conclusion

Correspondence to: Dr Li-Xia Xiong, Department of Pathophysiology, Medical College, Nanchang University, 461 Bayi Road, Nanchang, Jiangxi 330006, P.R. China

E-mail: xionglixia@ncu.edu.cn

Key words: breast cancer, metastasis, Notch, Jagged-1, Delta like canonical notch ligand 4

\section{Introduction}

Breast cancer is the most common cancer type in females, and the incidence rate has been steadily increasing worldwide over the past decade $(1,2)$. Breast cancer-associated mortality typically results from distant metastasis, rather than from the primary tumor (3). Despite recent advances in the application of targeted therapeutic strategies, no significant improvements in the prognosis of patients with metastatic breast cancer have been achieved due to the incomplete understanding of the molecular mechanisms governing the metastatic process.

Metastasis is a complex cascade involving interactions between cancer cells and surrounding microenvironmental components, including mesenchymal cells, immune cells and the extracellular matrix (4). The first stage of breast cancer metastasis is characterized by an invasion of the basement membrane by primary tumor cells, which then become disseminated tumor cells (DTCs) (5). These cells then promote abnormal angiogenesis, intravasate into the circulatory or lymphatic system, migrate to distant organs and establish secondary tumors (6).

Accumulating evidence has indicated the important role of Notch, a highly conserved family of signaling molecules, in breast cancer metastasis. The deregulation of Notch signaling is reflected in all aspects of the metastatic processes and its role in breast cancer appears to be highly context-dependent.

\section{Notch signaling}

Activation of Notch signaling requires interactions between ligands on the surface of signal-sending cells and Notch receptors (Notch1-4) on the surface of signal-receiving cells. Mammalian Notch signaling comprises two pathways: The canonical pathway and the non-canonical pathway (7).

The canonical Notch ligands include two homologs in Drosophila, Delta and Serrate. Their counterparts in mammals are Delta-like molecules (DLLs) and Jagged (7). The Notch receptors consist of an intracellular domain (ICD), a transmembrane domain and an extracellular domain (ECD) (8). Activation of canonical Notch signaling includes receptor and ligand binding, cleavage of the ICD, translocation of activated Notch ICD (NICD) into the nucleus and binding with chorionic somatomammotropin hormone like 1 (CSL; also termed $\mathrm{Rbp}-\mathrm{J} \kappa$ in mice and core-binding factor in humans). 
The receptor undergoes two cleavages on its S2 and S3 sites following Notch ligand-receptor ECD binding (8). Initially, the $\mathrm{S} 2$ site is cleaved by tumor necrosis factor- $\alpha$-converting enzyme, also termed ADAM metallopeptidase domain 17, in order to release the ECD (9). Subsequently, $\gamma$-secretase cleaves the $\mathrm{S} 3$ site to release NICD, which requires the involvement of presenilin (10). NICD then enters the nucleus and binds to CSL within its $\mathrm{Rbp}-\mathrm{J}_{\kappa}$-associated module region to modify target gene expression, including members of the HES and HEY family (11).

However, the understanding of non-canonical Notch signaling is primitive compared with that of the canonical one. Non-canonical Notch signaling has its distinctive ligands, including Delta-like 1, an integral membrane protein, microfibril-associated glycoprotein and a secreted ligand (12). Of note, activation of non-canonical Notch signaling does not require the participation of CSL; after the binding of the ligand and receptor, NICD is released and can therefore enter the nucleus directly (12).

\section{Notch and biased cell fate determinants}

In the orderly development of mammary tissues, the balance between differentiation and division is achieved by asymmetric divisions (ACD), which is controlled by several lineage-specific differentiation-inducing transcription factors (13). Through $\mathrm{ACD}$, the bi-potent mammary stem cells (MaSCs) divide into basal or luminal stem cells, and then become myoepithelial or ductal/alveolar cells respectively (14).

Notch signaling acts as an intrinsic regulator in the biological behavior of normal MaSCs (15). Notch signaling has been hypothesized to promote self-renewal proliferation and facilitate the myoepithelial lineage-specific commitment of MaSCs during the development of mammary glands (16). The cell fate developmental decisions of Notch signaling are negatively controlled by Numb, a protein asymmetrically located in dividing progenitor cells (17). Numb facilitates Notch ubiquitination at the membrane, promotes degradation of NICD, circumvents its nuclear translocation and inhibits activation of signaling downstream of Notch (18). However, in the case of overexpression of Notch components, the steady-state number of MaSCs may be disrupted, allowing mutant stem cells/breast cancer stem cells (BCSCs) to arise. These poorly differentiated BCSCs exhibit a high level of CD44; however, little or very low levels of CD24, resulting in a CD $44^{+} / \mathrm{CD} 24^{-/ \mathrm{lo}}$ phenotype (19). CD44 is a cell surface adhesion molecule that is enriched in basal-like breast cells (20). CD44 binds to hyaluronate and is associated with metastasis (21). While CD24 is a cell surface marker of differentiated breast luminal cells, cells with low expression of CD24 are usually basal-like (22). BCSCs are heterogeneous and can be subtyped into $\mathrm{CD} 44^{+} / \mathrm{CD} 24^{\text {lo }}$ progeny and $\mathrm{CD} 44^{+} / \mathrm{CD} 24^{-}$progeny regarding CD24 expression (23). Compared with $\mathrm{CD} 44^{+} / \mathrm{CD} 24^{-}$cells, CD $44^{+} / \mathrm{CD} 24^{\text {lo }}$ cells acquire significantly overexpressed Notch signaling components and upregulated embryonic stem cell transcription programs such as Notch1-mediated embryonic transcription factor Sox 2 activation, which may aid in explaining why the $\mathrm{CD} 44^{+} / \mathrm{CD} 24^{\text {lo }}$ progeny exhibits greater tumor initiating ability compared with CD $44^{+} / \mathrm{CD} 24^{-}$progeny (23). Notch1 overexpression also helps CD44+/CD24- cells convert into
CD $44^{+} / \mathrm{CD} 24^{\text {lo }}$ cells, and Notch 4 signaling has exhibited greater efficacy, when compared with Notch1 in the formation and maintenance of BCSCs, as Notch4-knockdown completely suppresses the tumor formation while Notch1-knockdown only reduces the tumor size and number (23).

The heterogeneity of BCSCs also confers it with drug-resistant ability. Notch inhibition had little effect in the CD $44^{+} / \mathrm{CD} 24{ }^{-}$subpopulation. However, peptides derived from Notch and Numb can activate cell-toxic lymphocytes to eliminate BCSCs, which provides a novel insight into breast cancer treatment (23).

Previous studies (24-26) have demonstrated that the cell fate determinants are disturbed in breast cancer cells due to loss of differentiation-inducing factors, including E74-like factor 5 (ELF5), ring finger protein (RNF8) and GATA binding protein 3 (GATA3), which is attributed to genetic abnormalities in Notch signaling.

ELF5 regulates MaSCs differentiation into the alveolar and luminal lineages through the Notch signaling pathway by binding to the responsive elements within the Notch gene (24). ELF5 may also inhibit breast cancer metastasis by suppressing the activation of Slug, a transcription factor in the epithelial-mesenchymal transition (EMT) process, and loss of ELF5 provides a basis for tumorigenesis (27). NICD1 and NICD4 are hyperactivated in ELF5-null mammary epithelial cells, which may be a strong initiator for the ELF5-null breast cancer phenotype (24). RNF8 affects breast cancer development and can also regulate the basal-to-luminal cell fate as well. It has observed to interact with Notch signaling by ubiquitylating NICD1 (25). Loss of RNF8 leads to the upregulation of Notch target genes and aberrant luminal progenitor cell expansion, resulting in an increased risk of mammary tumorigenesis (25). In addition, another differentiation-inducing factor GATA3, is also directly regulated by Notch3, through the CSL-binding motif in the GATA3 promoter $(26,28)$.

\section{Notch and local invasion}

Invasion of the basement membrane and mesenchyme. Specific gene programs equip cancer cells with increased mobility, which drives their migration away from primary sites (29). EMT constitutes the basis of the regulation of epithelial plasticity and cancer cell mobility. During this cascade process, epithelial cells lose their adhesion junctions and cellular polarity while acquiring mesenchymal characteristics $(30)$. In vitro studies $(31,32)$ have suggested that Notch1-knockdown reverses the Jagged1-induced EMT. These Notch1-silenced cells are capable of a less aggressive form of invasion, and may be characterized by a cobblestone-shaped phenotype rather than a spindle-like mesenchymal phenotype. Of note, numerous studies (32-37) have demonstrated that Jagged1-mediated Notch activation suppresses the levels of E-cadherin and increases the levels of the mesenchymal markers $\mathrm{N}$-cadherin and vimentin, the transcription factors Slug, Snail and zinc finger E-box binding homeobox 1 (Zeb1), as well as $\beta$-catenin in breast cancer cells to promote migration and invasion. However, to the best of our knowledge, the involvement of DLL in EMT has not been reported.

Signal transducer and activator of transcription 3 (STAT3) is an important pro-EMT transcription factor mediated by 
Notch (38). Notch1 has been hypothesized to activate EMT by inducing STAT3 and upregulating the expression of p65 and interleukin (IL)-1 (38). Notch2 has also been identified to promote EMT via the IL-6/Janus kinase (JAK)/STAT3 pathway in a radiation-driven model of breast cancer EMT (39). Notably, non-canonical Notch signaling was also identified to be involved in this pathway, with upregulation of IL-6 in breast cancer cells leading to the activation of JAK/STAT3 signaling (40). In the more aggressive triple-negative breast cancer, the loss of Numb leads to the activation of Notch signaling, and induces EMT and the acquirement of cancer stem cell-like properties, culminating in early relapse and metastasis $(41,42)$. Other mobility-promoting programs, including F-actin polymerization, may also be induced by Notch1 (43).

However, Notch3 serves the opposite role in EMT by regulating estrogen receptor $\alpha(\mathrm{ER} \alpha)$. $\mathrm{ER} \alpha$ is characteristic of luminal epithelial phenotype in breast cancer cells, the loss of which causes EMT and metastasis (44). Notch3 stimulates ER $\alpha$ expression not only by directly binding to CSL-binding elements in ER $\alpha$ promoter, but also indirectly by upregulating GATA-3 (an activator of ER $\alpha$ ) (28). These two patterns result in ER $\alpha$ overexpression and thus suppress EMT.

Enhanced migratory ability alone, however, is insufficient to drive metastasis. Disseminating cancer cells must also invade the surrounding complex network, which primarily consists of extracellular matrix (ECM), basement membrane and mesenchyme (5). The matrix metallopeptidase (MMP) family is known to degrade the ECM and promote cancer cell invasion and metastasis (45). In breast cancer, Notch1 activation promotes the expressions of MMP-2 and -9 to break down the ECM components (46). Notch has also been demonstrated to be associated with urokinase-type plasminogen activator (uPA), which is an ECM-degradation enzyme associated with poor outcome, and a high risk of metastasis and recurrence (47). Under normal conditions, uPA induces a plasminogen proteolytic sequence. However, in breast cancer, uPA works with MMPs to erode the microvasculature and degrade the ECM to facilitate tumor cell metastasis. uPA receptor (UPAR) is highly expressed in malignant tissues and tends to be located at the leading edge or invasion front (48). Upon binding to uPA, the receptor converts plasminogen to plasmin, then degrades ECM through MMP (48). A precious study placed Notch upstream of the uPA cascade (49). A positive association has been observed between Jagged1 and UPA in various breast cancer cell lines, and Notch1-knockdown reduced uPA levels (49). Furthermore, Notch may directly regulate uPA transcription via centromere-binding factor 1 binding sites within the uPA promoter and enhancer. The subsequently activated uPAR then cleaves ECM-associated signaling molecules, including fibronectin and the laminin receptor $(49,50)$.

Hypoxia. Hypoxia is a term for a low-oxygen environment, and may be the result of leaky vasculature and a lack of blood supply, and is important for tumor progression (51). Hypoxia-inducible factor $1 \alpha(\mathrm{HIF}-1 \alpha)$ promotes metastasis and is associated with poor prognosis (52-54). Accumulation of HIF-1 $\alpha$ and HIF-2 $\alpha$ enhance Notch signaling (both receptors and ligands) as well as the expression of the downstream genes HES1 and HEY1; HIFs and mastermind-like protein (MAML)1, a key Notch co-activator, form a complex with NICD to recruit other Notch co-activators, including p300, indicating a HIF/MAML1/Notch axis under hypoxia (33). Hypoxia stabilizes HIFs through this signaling cascade, resulting in elevated Notch (33).

Hypoxia-induced Notch activation causes EMT in breast cancer (55). Furthermore, NICD directly binds to the Snail-1 promoter (56). In addition, Notch potentiates HIF-1 $\alpha$ to bind to the lysyl oxidase (LOX) promoter and then stabilizes the secretion of Snail-1 and tissue inhibitor of metalloproteinase (TIMP)4, leading to EMT and metastasis $(57,58)$. Consistent with its ability to simulate ECM degradation, LOX correlates with estrogen receptor (ER)-negative breast cancer, which is more likely to metastasize to the bone compared with ER-positive breast cancer (59). The ability of LOX to induce metastasis indicates that it may serve as a novel target to prevent bone metastasis of breast cancer.

Interaction between breast cancer cells and stromal cells. The tumor microenvironment, which primarily consists of mesenchymal cells and immune cells, is central to the progression of breast cancer (60). Solid experimental evidence has indicated that cancer-associated fibroblasts (CAFs) secrete cytokines to support breast cancer cells and protect them from host surveillance (61). CAFs secrete ADAM10-rich exosomes, which in turn were recently identified to be associated with loss of TIMP family member expression, to potentiate cell motility and aldehyde dehydrogenase (ALDH) expression through Ras homolog family member A and Notch, respectively (62). Silencing of Notch effector Rbp-J $\mathrm{J}_{\mathrm{K}}$, combined with downregulation of the tumor suppressor $\mathrm{p} 53$, induces a senescent phenotype and the expression of CAF effector genes (63).

Immune regulation also serves an important role in breast cancer progression. $\mathrm{CD}^{+} \mathrm{T}$ cell infiltration, together with type 1 interferon, activates innate immunity, acting as an anti-tumor mechanism in breast cancer (64). It has been reported that Notch signaling controls $\mathrm{CD}^{+} \mathrm{T}$ cell activation through the binding of DLL1 with Notch1 or Notch2 (65). Notch1 has a crucial role in the immune-suppressive tumor microenvironment and the inhibition of Notch1 leads to recruitment of active $\mathrm{CD}^{+} \mathrm{T}$ cells and a decrease of immune suppressive cells, regulatory $\mathrm{T}$ cells (Tregs) and myeloid-derived suppressor cells (MDSCs) (66). However, Notch2 contributes to the anti-tumor response, and the deletion of $\mathrm{CD}^{+} \mathrm{T}$ cell specific Notch 2 in mice results in increased tumor size and decreased survival in tumor-bearing mice (67). Thus, Notch signaling has a dual role in regulating the tumor immune response, as it may exert oncogenic and tumor suppressive functions. Notch signaling may also act as a transcriptional regulator in the differentiation of tumor-associated macrophages (TAMs). TAMs may recruit Tregs and MDSCs and also suppress $\mathrm{CD}^{+} \mathrm{T}$ cells (68). CSL deletion in monocytes inhibits not only differentiation, but also the antigen-presenting function of TAMs, restraining the immune-suppressive function of TAMs (69). Of note, overexpression of NICD has been reported to suppress the function of TAMs and then repress tumor growth, indicating that the effects of Notch signaling on TAMs may depend on the extent of Notch signaling (70).

Angiogenesis. Breast cancer cell multiplications requires a lot of nutrition, as the original blood vessels at the site of the 
tumor are insufficient to the amount of nutrition for the rapid growth of breast cancer cells (71). Therefore, breast cancer cells exhibit an angiogenic phenotype that allows new blood vessels to branch and create a massed vascular network (72). In addition to transport nutrition, these immature and highly permeable new blood vessels also provide an efficient route of exit for breast cancer cells to leave the primary site and enter the circulation, which can then elicit metastasis (73). In the process of angiogenesis, Notch ligands, together with vascular endothelial growth factor (VEGF), the strongest mitogenic factor, stimulates the formation of vascular endothelial cells to establish a neovasculature (74), which then promotes breast cancer metastasis.

In vascular endothelial cells, the ends of vessel sprouts are termed tip cells and the other cells are called stalk cells (75). These cell types are essential for vessel polarity and barrier function of vessels (76). This endothelial cell specification is regulated by Notch signaling during tumor angiogenesis process, with the two types of Notch ligands exerting the opposite effects (77).

In normal conditions, VEGF receptor (VEGFR) signaling serves as an initiator in tip cell formation, while DLL4 serves an inhibitory role (78). Upregulation of DLL4 by VEGF/VEGFR in endothelial tip cells suppresses the tip-like phenotype; therefore, the single tip cell can be selected from among many candidate vascular endothelial cells and form the new vessel sprout (78-80). To avoid the excessive tip cell formation and immoderate angiogenesis, high level of DLL4 signals are sent to the adjacent cells (stalk cells) through Notch1, which then inhibits the expression of VEGFR in stalk cells and induces vascular network quiescence (81). Jagged-1, another type of ligand, is not directly associated with sprouting angiogenesis, but shifts the balance between DLL4/Notch and VEGFR signaling (82). Jagged-1 primarily exists in stalk cells and can antagonize DLL4/Notch signaling in stalk cells to ameliorate the low VEGF response, thus activating stalk cells to promote angiogenesis (80). These processes are mediated by the glycosyltransferase Fringe family, which results in Notch binding to DLL4 more easily; however, impedes its ability to bind to Jagged-1 (83). However, in metastatic breast cancer, overexpression of Jagged-1 transforms angiogenesis from physiological to pathological patterns that favors metastasis. This causes excessive angiogenesis and even gives rise to a new hybrid tip/stalk phenotype $(84,85)$. Therefore, it is well demonstrated that hybrid tip/stalk phenotype leads to the formation of new sprouts; however, new blood vessels produced under these conditions exhibit poor perfusion with high microvessel density, which is what metastatic DTCs require. These pathological blood vessels confer great plasticity to the leading cell that have are capable of exchanging its position with adjacent stalk cells rapidly, thus creating a fast but chaotic and dense vascular network route for a large number of DTCs to exit the primary sites (84).

Demethylases and Notch-associated proteases also dynamically participate in angiogenesis in breast cancer, and the overexpression of the lysine demethylase 2A (KDM2A) in human breast cancer is associated with a worse outcome. Jagged1 is essential for KDM2A-driven tumor angiogenesis and acting as a direct target of KDM2A (86). Inhibition of KDM2A in breast cancer cells blocks Notch activation and endothelial cell tube formation (87). Proteases including MMPs are able to make space for angiogenesis and lymphangiogenesis (45). In addition, uPA and UPAR may combine to activate VEGF (49).

Intravasation. Notch signaling modulates the ability of breast cancer cells to cross mesenchymal and endothelial barriers (87). Integrins are associated with normal mammary epithelial cells, as well as with breast cancer cells (88). A feedback loop has been reported between integrins and Notch, and is characterized by activated Notch signaling controlling $\beta 1$ integrin affinity, while $\beta 1$ integrin inhibits the expression of Notch $(89,90)$. $\beta 1$ integrin cooperates with Notch to promote the transendothelial migration of breast cancer cells, which is characterized by enhanced polarity reversal and adhesion to the blood vessel wall $(91,92)$.

Aberrant Notch activation stimulates endothelial cells to promote breast cancer intravasation. Vascular cell adhesion molecule-1 may be subverted by Notch1 to enhance the adhesion of tumor cells and neutrophils to endothelial cells, thus favoring the dissemination of tumor cells (93). As stated previously, breast cancer cells may also recruit factors including MMPs that increase vascular permeability and thus promote intravasation (Fig. 1).

\section{Notch and survival in circulation}

Breast cancer cells detach from primary sites and then enter the circulation, becoming circulating tumor cells (CTCs) (94). CTCs must first survive in the bloodstream prior to arriving at distant organs (95).

Anti-apoptotic effects. Apoptosis negatively regulates tumor progression by preventing overgrowth. This process depends on the coordination of numerous ligands and receptors, including tumor necrosis factor-related apoptosis-inducing ligand (TRAIL)/TRAIL-receptor1 and 2, also termed DR4 and DR5 (96). Administration of $\gamma$-secretase inhibitors (GSIs) may lead to a marked upregulation of DR4 and DR5, increase the sensitization of breast cancer cells to TRAIL-mediated apoptosis (96), activate the caspase system (i.e. caspase-8) (97), promote mitochondrial membrane leakiness and further induce apoptosis. This Notch-mediated anti-apoptosis function may depend on activator protein (AP)1, which is a dimeric transcription factor complex activated by c-Jun N-terminal kinase (JNK) (96). Blocked by GSIs, Notch fails to be activated, which increases the levels of AP1 and JNK $(96,98,99)$, thus activating DR4 and DR5 (100). A recent study indicated that Notch4, but not Notch1, is involved in the sensitization of breast cancer cells to TRAIL-induced apoptosis (101). Alternatively, inhibition of $\beta 1$ integrins may sensitize tumor cells to TRAIL-induced apoptosis, which is mediated by Notch (102). The GSI/TRAIL combination also decreases several survival factors, including survivin and B-cell lymphoma 2 (96). Furthermore, different types of breast cancer cell differ in their response to such inhibition. For example, ER-negative breast cancer cells are more sensitive to GSI/TRAIL synergism compared with ER-positive cells (96).

AKT impedes DNA damage-induced apoptosis via inhibition of apoptosis signal-regulating kinase 1, which in 


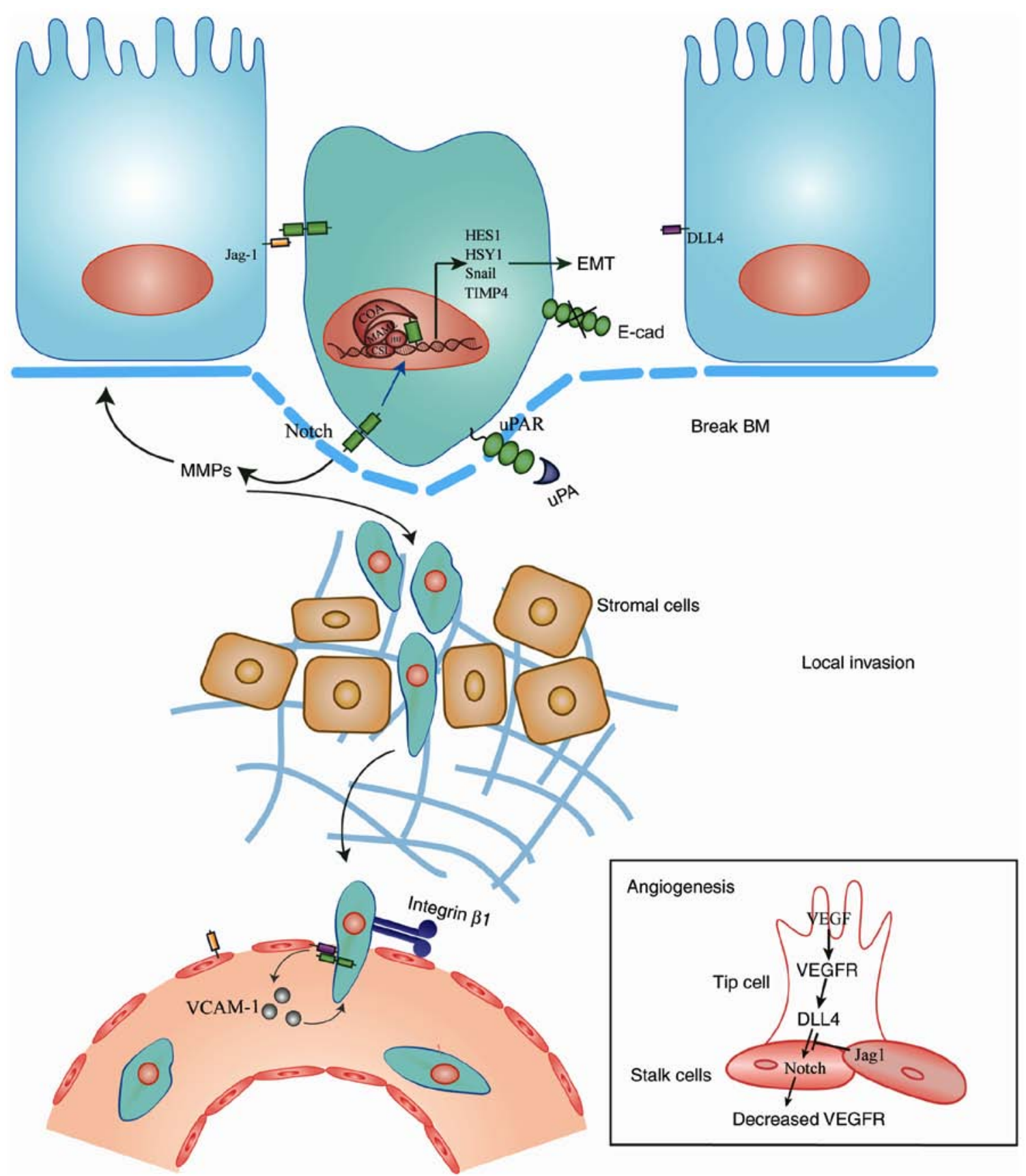

Figure 1. BC DTCs detach from primary sites and intravasation. BC DTCs obtain increased motility to break the BM and overcome ECM with Notch-associated processes such as hypoxia and EMT, as well as enzymes, including MMPs and uPA. Notch takes part in angiogenesis to sprout new vessels and BC DTCs can enter the bloodstream through these vasculatures. BC, breast cancer; DTCs, disseminated tumor cells; ECM, extracellular matrix; MMP, matrix metalloproteinase; uPA, urokinase-type plasminogen; uPAR, urokinase-type plasminogen receptor; BM, basement membrane; TIMP4, tissue inhibitor of metalloproteinase 4; EMT, epithelial-mesenchymal transition; DLL4, Delta-like molecule 4; VCAM-1, vascular cell adhesion protein 1; Jag-1, Jagged-1; VEGF, vascular endothelial growth factor; VEGFR, vascular endothelial growth factor receptor.

turn prevents JNK-mediated activation of p53 (103), leading to an aberrant increase of mammary progenitor cells (104). Substantial evidence has demonstrated that impairment of Notch signaling may inhibit AKT activity and sensitize cells to apoptosis $(103,105)$. It has also been reported that the addition of DAPT, a GSI, improves the anti-tumor efficacy of RY10-4, an anti-breast cancer drug, due to the accessorial restraint on AKT phosphorylation exhibited by DAPT, which reduces the survival of breast cancer cells (106).

Notch-mediated regulation of AKT contributes to tumor cell survival through multiple pathways. AKT is hypothesized to increase MMP production via several downstream target proteins, including nuclear factor (NF) $\kappa \mathrm{B}$ and mammalian target of rapamycin (mTOR) (106). Li et al (46) suggested that Notch1 inhibition enhances protein phosphatase 2A (PP2A) activity and downregulates $\mathrm{NF}-\kappa \mathrm{B}$, which may be restored by the PP2A inhibitor okadaic acid (OA). Treatment with OA also upregulates VEGF, MMP2 and MMP9, suggesting a key role of PP2A in the Notch/AKT/NF- $\mathrm{BB}$ axis (107). mTOR also takes part in AKT-mediated tumor cell survival, a mechanism contributing to chemoresistance (108). Its downstream effector, eukaryotic initiation factor $4 \mathrm{E}$, is crucial for mTOR-mediated 
inhibition of p53 and may reverse p53-mediated cytotoxicity (109). Furthermore, Notch activation enhances the activity of MDM2, an E3 ubiquitin-protein ligase, to also degrade p53 (110). Apart from these indirect Notch/p53 signaling pathways, Notch also directly binds to the amino terminus of p53 without the presence of AKT, thus inhibiting p53 phosphorylation and DNA-binding activity (111).

Chemoresistance. To overcome the threat of chemotherapy, CTCs must employ several sophisticated approaches. To contend with chemotherapeutic agents for breast cancer, CTCs may acquire morphological and functional endothelial features characteristic of tumor vascularization (112). DLL3 and Notch4, with their downstream targets p65 (an NF-kB subunit) and Zeb1, are overexpressed in tumor-derived endothelial cells during chemotherapy (113). Silencing of Notch4/DLL3 may decrease the functionality of tumor-derived endothelial cells and endothelial markers (113). The expression of VEGFR3, an important factor in tumor angiogenesis, is significantly upregulated in patients receiving chemotherapy. Notch4/DLL3 silencing also suppress the expression of VEGFR 3 transcripts, indicating that breast cancer chemotherapy triggers the formation of functional tumor-derived endothelial vessels by regulating Notch and VEGF signaling (113).

Patients with ER-positive breast cancer with high levels of ALDH1 and Notch4 exhibit poor prognosis following anti-estrogen treatment (114). Although short-term treatment suppresses tumor cell proliferation, it also increases CTC activity through Jagged1/Notch4 activation, as the administration of Notch inhibitors attenuates drug resistance and improves patient outcomes (114). Long-term hormonal therapies may reduce $E R \alpha$ expression and increase the levels of IL-6, thus enhancing the self-renewal properties of hormonal therapy-resistant ER-dependent, as well as ER-independent tumor cells. Subsequently, IL-6 may cause a departure from metabolic dormancy induced by mitochondrial activation through an IL-6/STAT3/Notch3 transduction pattern, hence leading to the acquirement of resistance (115). Blocking IL-6 reduces the levels of STAT3/Notch3 in breast cancer cells, resulting in increased sensitivity to hormonal therapy such as tamoxifen (115). In addition, STAT1 may also facilitate the expansion of therapy-resistant breast cancer cells via Notch3 (116).

Of note, multiple courses of treatment for patients with ER-positive/human epidermal growth factor receptor 2 (HER2)-negative breast cancer may endow their CTCs with HER2 expression (117). A further study demonstrated that breast cancer CTCs that underwent this transformation maintain discrete HER2-positive and HER2-negative subpopulations (118). Of note, HER2-positive and HER2-negative breast cancer CTCs may spontaneously interconvert; however, have different functions. HER2-positive CTCs acquire a stronger proliferation potential and a higher lung metastasis frequency but are no more sensitive to HER2-targeted therapy, while HER2-negative CTCs exhibit an increased expression of Notch1 but a resistance to chemotherapy. Therefore, dual treatment in Notch inhibitor-sensitive HER2-negative/Notch-positive and chemotherapy-sensitive HER2-positive/Notch1-negative CTCs may be a reasonable approach (118).

\section{Notch and secondary colonization}

Prior to establishing metastases in secondary organs, breast cancer CTCs release factors, including MMPs, and gather bone marrow-derived hematopoietic precursor cells to combine with perivascular fibroblasts and fibronectin to form the pre-metastatic niche (29). Once CTCs extravasate and colonize the niche, they become micrometastases (29).

The mechanism underlying metastatic organotropism remains largely elusive; specifically, no rationale for the propensity of breast cancer to metastasize to the bone, lung and liver has been proven thus far. However, evidence has revealed that bone metastasis of breast cancer may arise with the help of Notch. In bone, breast cancer cells may employ numerous signaling pathways, including Notch, to mediate osteoblast activation and differentiation (119). Bone marrow osteoblasts produce transforming growth factor- $\beta$, which increases the levels of the Notch signaling proteins Notch 3 and Jagged1, thus promoting the secretion of osteoblast-derived IL-6 and osteoblast differentiation $(120,121)$. Inhibition of Notch signaling via knockdown of Notch3 or treatment with a GSI markedly decreases breast cancer bone metastasis (Fig. 2) $(120,121)$.

KiSS1, a metastasis suppressor gene, is downregulated in breast cancer secondary tumor sites (122). By enhancing the activation of inhibitor of NF- $\kappa B$, KiSS1 prevents NF- $\kappa B$ binding to the promoters of pro-inflammatory and pro-metastatic genes, thus potentially competing with Notch (122). Furthermore, KiSS1 encodes a $\mathrm{COOH}$-terminally amidated active peptide, metastin (123). Of note, metastin only affects secondary tumor sites but not primary lesions (123).

$\mathrm{Nm} 23$ is also a suppressor of breast cancer metastasis (124). The Nm23 protein, particularly the Nm23-H1 isoform, has three major targets: ATP citrate lyase (involved in metabolism), aldolase $\mathrm{C}$ (involved in hypoxia) and kinase suppressor of Ras (involved in regulation of mitogenic activity) (124). Furthermore, Nm23 may suppress several metastasis-associated factors, including Smoothened (a key receptor in Hedgehog signaling) and pleiotrophin (29). Treatment with non-steroidal anti-inflammatory drugs may upregulate Nm23 expression, thus inhibiting Notch/HES1 and reducing CTCs $(125,126)$. Ignesti et al (127) suggested that loss of Drosophila awd, a homolog of Nm23, may inhibit Notch signaling following S2 cleavage.

Expression of tenascin C (TNC), an ECM protein located in the stem cell niche, is an effective biomarker for breast CTCs that have infiltrated the lung (128). TNC enhances the level of musashi homolog 1 (MSI1), a regulator of Notch signaling, and thus confers enhanced migratory and invasive properties to breast CTCs (128). High levels of MSI1 and Jagged1 are indicative of a poor prognosis $(129,130)$. Notably, cancer-induced sprouting neovasculature may induce tip cells to secret periostin [POSTN; Notch1 associates with POSTN at epidermal growth factor repeats $(131,132)]$ to bind to TNC and then ECM, and facilitate TNC deposition on the ECM and its incorporation into the ECM (133).

It is incumbent on DTCs to expand and establish new colonies; otherwise, these cells enter dormancy, which is defined as growth arrest, a balance between proliferation and apoptosis (134). Dormant breast DTCs in the lung may be experiencing an absence of uPA- and $\alpha 5 \beta 1$ integrin-triggered 


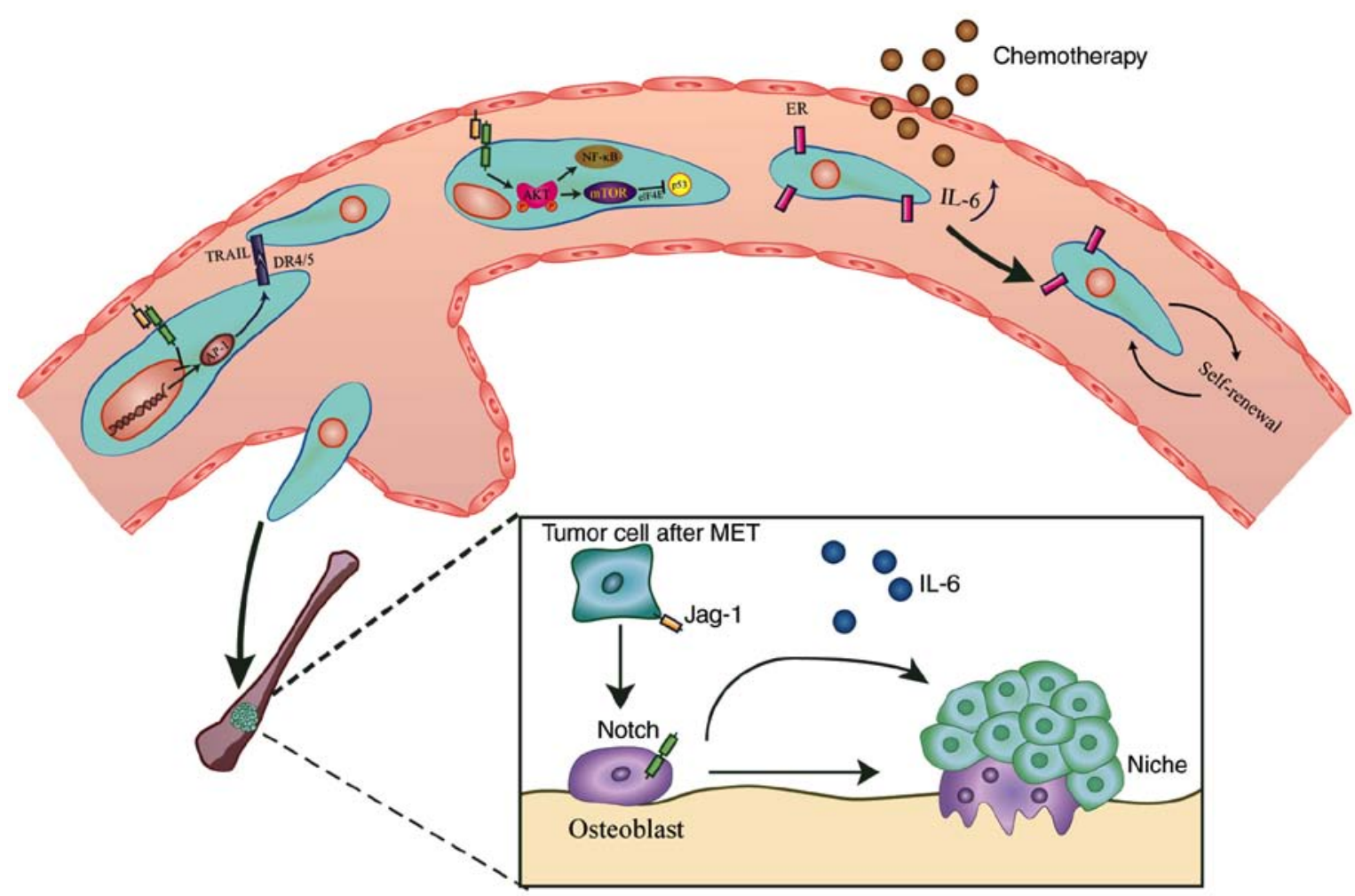

Figure 2. BC CTCs survives in the bloodstream and colonize in bone. Notch helps BC CTCs to survive from TRAIL apoptosis systems and the tumor suppressor gene p53. Chemotherapies increase the IL-6 level by the IL-6/STAT3/Notch3 axis to enhance the self-renewal properties of ER-positive BC. Notch also facilitates bone metastasis of BC by regulating osteoblasts activation and differentiation. BC, breast cancer; CTC, circulating tumor cell; TRAIL, tumor necrosis factor-related apoptosis-inducing ligand; Jag-1, Jagged-1; IL, interleukin; ER, estrogen receptor.

proliferative signaling (135). Re-activation of dormant cells calls for increased uPAR- $\alpha 5 \beta 1$ integrin complexes and activation of upstream Notch signaling (135). Notch3 is responsible for the stability of mitogen-activated protein kinase phosphatase-1 (MKP-1), a widely expressed phosphatase (136). A previous study demonstrated that the levels of Notch3 and MKP-1 are relatively low in dormant tumors, resulting in high levels of phosphorylated p38, a target of MKP-1 that contributes to the maintenance of dormancy (137).

\section{Notch-associated microRNAs in breast cancer metastasis}

MicroRNAs (miRNAs) are a series of endogenous small single-stranded non-coding RNAs that are $\sim 18-24$ nucleotides in length (138). miRNAs regulate the expression of endogenous genes by complementary base pairing at the transcriptional or post-transcriptional levels (139). Over the past decade, the abnormal expression of miRNAs has been observed in nearly all malignant tumor types; therefore, miRNAs are considered to be an emerging oncology research direction (140). Certain miRNAs have been reported to be associated with Notch signaling, while a number of them are aberrantly expressed in breast cancer and are therefore associated with promoting metastasis.

The miR-34 family member miR-34a is highly expressed in normal mammary tissues; however, it is significantly downregulated in breast cancer tissues (141). miR-34a has been demonstrated to function as an important tumor suppressor by regulating a variety of tumor progression steps, including cell proliferation, invasion and apoptosis, and
Notch, which is a target gene of miR-34a (142). In metastatic breast cancer cells, overexpression of miR-34a significantly increases the protein level of tumor suppressor gene p53 and decreases the expression of Notch1, thereby inhibiting cell proliferation, invasion and inducing apoptosis $(143,144)$. Additionally, miR-34a can sensitize metastatic breast cancer cells to paclitaxel and adriamycin (chemotherapeutic drugs for breast cancer) partly by downregulating Notch1 expression (142,145). miR-34a and miR-34c, another member of miR-34 family, have been reported to prevent self-renewal and differentiation of BCSCs $(146,147)$. Their expression is also at a very low level in BCSCs. Overexpression of miR-34a and miR-34c suppresses stemness by targeting Notch1 and Notch4, respectively $(145,147)$. Two prognostic factors miR-1179 and miR-3178 are downregulated in breast cancer and have both been demonstrated to target Notch signaling. miR-1179 is a newly identified miRNA in 2018 (148). Clinicopathological analysis revealed that decreased miR-1179 expression in breast cancer was correlated with advanced clinical stage and lymph node metastasis (149). Upregulated miR-1179 suppresses the breast cancer vitality and motility, by inhibiting the expression of Notch1, Notch4 and their downstream Hes1 (149). miR-3178 is a prognostic factor, particularly in TNBC, and its ectopic overexpression can inhibit metastasis by blocking Notch1-induced EMT (150). In addition, miR-9 can reduce metastatic behaviors in TNBC by targeting Notch1 (151).

However, miRNAs do not all function as tumor suppressors in breast cancer, some have been observed to also promote metastasis. Notch3 can inhibit EMT in breast cancer and directly target miR-221/222 (152). By directly binding to 
the 3'-untranslated region of Notch3 and inhibiting its translation, miR-221/222 exerts an oncogenic role by promoting EMT (152). miR-146a is also upregulated in BCSCs, and activates Notch signaling by targeting the Notch suppressor Numb $(153,154)$.

\section{Application of Notch signaling in the clinical treatment of breast cancer}

Current treatments for metastatic breast cancer (BC) are predominantly palliative with little clinical efficacy (155). Encouragingly, numerous studies have focused on the treatment of metastatic BC via targeting Notch signaling. $\gamma$-secretase inhibitors exhibit great potential, for example, PF-03084014 (Pfizer Oncology), a small molecule selective noncompetitive and reversible GSI, displays synergistic activity with docetaxel and has demonstrated significant antitumor activity in a patient with triple-negative BC (156). In addition, a potent non-competitive oral GSI, MK-0752 (MERK), has been evaluated for the treatment of metastatic BC via induction of G0/G1 arrest (157). Monoclonal antibodies against DLL4, including REGN421/SAR153192 (Regeneron Pharmaceuticals), OMP-21M18, OMP-59R5 and OPM-52M51 (OncoMed Pharmaceuticals), which target Notch 2/3 and Notch 1 receptors, have also been investigated in clinical trials (158). Additionally, BXL0124, a Gemini vitamin $\mathrm{D}$ analog, has been demonstrated to be effective in suppressing CD $44^{+} / \mathrm{CD} 24^{-/ / 0}$ BCSCs in basal-like BC through HES1-mediated Notch1 inhibition (159). Although numerous drugs are in development, significant challenges still exist before a Notch-targeted therapeutic strategy can be clinically applied. For example, patients with $\mathrm{BC}$ receiving continuous doses of MK-0752 at $450 \mathrm{mg} /$ daily present with symptoms of toxicity and fatigue (160). Furthermore, gastrointestinal toxicity is also a major side effect in patients treated with GSIs (161).

In recent years, cancer immunotherapy has demonstrated striking improvements in long-term survival (162), which has had a large impact on conventional systemic cancer therapy. Studies have revealed a key role of Notch in breast cancer immunotherapy. Notch1 depletion improves the efficacy of anti-tumor drugs, nivolumab (anti-programmed death-1 (PD-1) antibody) and ipilimumab (cytotoxic $\mathrm{T}$ cell-associated antigen-4 (CTLA-4) antibody) (66). PD-1 and CTLA-4 are inhibitory receptors on the surfaces of $\mathrm{T}$ cells, which can abrogate $\mathrm{T}$ cell activation when binding to ligands (163), and BC cells can express their ligands (PDL1 and B7 for PD-1 and CTLA-4, respectively), thereby deactivating cytotoxic $\mathrm{T}$ cells and attenuating the immune response.

\section{Conclusion}

Breast cancer is therapeutically challenging due to its distant metastasis. Recurrence at distant organs suggests that the dissemination of tumor cells may occur at very early, typically asymptomatic stages. Notch signaling modulates breast cancer metastasis in many links, and different receptors and ligands serve distinct roles $(32-34,36-43,46)$. Notch3, however, can exert oncogenic or anti-oncogenic functions in cancer progression in a context dependent manner. By modulating
GATA3 and ER $\alpha$, Notch3 suppresses EMT and metastasis in breast cancer $(28,44)$. Notch3 is also negatively associated with chemoresistance, and it has been reported that the overexpression of Notch3 results in low degree of breast cancer chemoresistance (164). Of note, breast cancer metastasis exhibits organotropisms (165), and Notch3 has been reported to be associated with bone metastasis. Notch 3 enhances bone metastasis by increasing the secretion of transforming growth factor $\beta 1$ by osteoblasts, thus activating the colony formation of breast cancer cells (120).

In order to promote primary tumor cell dissemination, Notch signaling can either trigger or inhibit EMT by interacting with downstream effectors $(28,38-44)$, then regulating the invasion of breast cancer cells through the mesenchyme and basement membrane (62-70). With the help of the neovascular network, Notch signaling further initiates anti-apoptotic (96-100) and chemoresistant (114-116) characteristics in circulation and secondary colonization, which facilitate metastasis to distant organs. However, the mechanism of metastasis remains elusive. For example, certain patients carrying DTCs never develop metastasis, while other patients with large metastases do not present with DTCs at the time of primary tumor detection.

Another topic of interest in breast cancer research is exosomes, which are cell-derived vesicles that contain various biomolecules of their cell origin, such as DNA, RNA and proteins (166). It has been demonstrated that exosomes can regulate therapy resistance of breast cancer via exosomal RNA (exoRNA) transferring from stromal cells of the tumor microenvironment to breast cancer cells (116). The exoRNA can activate the RIG-I receptor (a subtype of pathogen recognition receptor) on breast cancer cells to induce STAT1 expression, which then facilitates Notch target genes expression in breast cancer cells, resulting in the upregulation of Notch3 signaling and an increase in chemoresistant BCSCs (116). In addition, exosomes have also been observed to enable organotropic metastasis by preparing a pre-metastatic niche, which is achieved through the fusion of the specific integrin (ITG) and organ-specific resident cells (167). Exosomes have also been shown to correlate with immune modulation and apoptosis in breast cancer (168). Therefore, the interaction between exosomes and Notch should be the focus of additional investigations, and exosomes may be a potential research target in breast cancer in the future.

Investigation of only one signaling pathway is also insufficient for the development of appropriate therapy, since the activation of associated pathways as well as the cross-talk between Notch and other signaling pathways are of critical importance in breast cancer metastasis. Specific aspects that will be important to consider include TNC stimulation of Notch and WNT signaling to balance dormancy and activation (128). Furthermore, Notch is also associated with the Hedgehog signaling pathway, which then regulates the tumor immunity response $(169,170)$. However, the complicated mechanisms of metastasis reveal just the tip of the iceberg, and the presently available knowledge of Notch signaling and BC metastasis is insufficient.

\section{Acknowledgements}

Not applicable. 


\section{Funding}

This study was funded by a grant from the National Science Foundation of China (grant. no. 31860317).

\section{Availability of data and materials}

Not applicable.

\section{Authors' contributions}

YZ was responsible for the conception and design of the review, and the drafting of the manuscript. $\mathrm{ZX}$ and $\mathrm{XG}$ were responsible for collecting the evidence and revising the manuscript. XX and LX gave final approval of the present version of the manuscript to be published. All authors read and approved the manuscript and agreed to be accountable for all aspects of the research in ensuring that the accuracy or integrity of any part of the work are appropriately investigated and resolved.

\section{Ethics approval and consent to participate}

Not applicable.

\section{Patient consent for publication}

Not applicable.

\section{Competing interests}

The authors declare that they have no competing interests.

\section{References}

1. Siegel RL, Miller KD and Jemal A: Cancer Statistics, 2017. CA Cancer J Clin 67: 7-30, 2017.

2. Chen W, Zheng R, Baade PD, Zhang S, Zeng H, Bray F, Jemal A, Yu XQ and He J: Cancer statistics in China, 2015. CA Cancer J Clin 66: 115-132, 2016.

3. Wu Y, Shao A, Wang L, Hu K, Yu C, Pan C and Zhang S: The role of lncRNAs in the distant metastasis of breast cancer. Front Oncol 9: 407, 2019.

4. Spill F, Reynolds DS, Kamm RD and Zaman MH: Impact of the physical microenvironment on tumor progression and metastasis. Curr Opin Biotechnol 40: 41-48, 2016.

5. Wan L, Pantel K and Kang Y: Tumor metastasis: Moving new biological insights into the clinic. Nat Med 19: 1450-1464, 2013.

6. Kozłowski J, Kozłowska A and Kocki J: Breast cancer metastasis-insight into selected molecular mechanisms of the phenomenon. Postepy Hig Med Dosw (Online) 69: 447-451, 2014.

7. Bray SJ: Notch signalling in context. Nat Rev Mol Cell Biol 17: 722-735, 2016.

8. Bray SJ: Notch signalling: A simple pathway becomes complex. Nat Rev Mol Cell Biol 7: 678-689, 2006.

9. Brou C, Logeat F, Gupta N, Bessia C, LeBail O, Doedens JR, Cumano A, Roux P, Black RA and Israël A: A novel proteolytic cleavage involved in Notch signaling: The role of the disintegrin-metalloprotease TACE. Mol Cell 5: 207-216, 2000.

10. Sprinzak D, Lakhanpal A, Lebon L, Santat LA, Fontes ME, Anderson GA, Garcia-Ojalvo J and Elowitz MB: Cis-interactions between Notch and Delta generate mutually exclusive signalling states. Nature 465: 86-90, 2010.

11. Wu L, Aster JC, Blacklow SC, Lake R, Artavanis-Tsakonas S and Griffin JD: MAML1, a human homologue of Drosophila mastermind, is a transcriptional co-activator for NOTCH receptors. Nat Genet 26: 484-489, 2000 .
12. D'Souza B, Miyamoto A and Weinmaster G: The many facets of Notch ligands. Oncogene 27: 5148-5167, 2008.

13. Visan I: Asymmetric division. Nature Immunol 13: 120, 2012.

14. Santoro A, Vlachou T, Carminati M, Pelicci PG and Mapelli M: Molecular mechanisms of asymmetric divisions in mammary stem cells. EMBO Rep 17: 1700-1720, 2016.

15. Bouras T, Pal B, Vaillant F, Harburg G, Asselin-Labat ML, Oakes SR, Lindeman GJ and Visvader JE: Notch signaling regulates mammary stem cell function and luminal cell-fate commitment. Cell Stem Cell 3: 429-441, 2008.

16. Dontu G, Jackson KW, Mcnicholas E, Kawamura MJ, Abdallah WM and Wicha MS: Role of Notch signaling in cell-fate determination of human mammary stem/progenitor cells. Breast Cancer Res 6: R605-R615, 2004.

17. Rhyu MS, Jan LY and Jan YN: Asymmetric distribution of numb protein during division of the sensory organ precursor cell confers distinct fates to daughter cells. Cell 76: 477-491, 1994.

18. McGill MA and McGlade CJ: Mammalian numb proteins promote Notch1 receptor ubiquitination and degradation of the Notch1 intracellular domain. J Biol Chem 278: 23196-23203, 2003.

19. Honeth G, Bendahl PO, Ringnér M, Saal LH, Gruvberger-Saal SK, Lövgren K, Grabau D, Fernö M, Borg A and Hegardt C: The CD $44^{+} / \mathrm{CD} 24-$ phenotype is enriched in basal-like breast tumors. Breast Cancer Res 10: R53, 2008.

20. Calaf GM, Ponce-Cusi R and Abarca-Quinones J: Effect of curcumin on the cell surface markers CD 44 and CD24 in breast cancer. Oncol Rep 39: 2741-2748, 2018.

21. Huiping L, Patel MR, Prescher JA, Patsialou A, Qian D, Lin J, Wen S, Chang YF, Bachmann MH, Shimono Y, et al: Cancer stem cells from human breast tumors are involved in spontaneous metastases in orthotopic mouse models. Proc Natl Acad Sci USA 107: 18115-18120, 2010

22. Shipitsin M, Campbell LL, Argani P, Weremowicz S, Bloushtain-Qimron N, Yao J, Nikolskaya T, Serebryiskaya T, Beroukhim R, Hu M, et al: Molecular definition of breast tumor heterogeneity. Cancer Cell 11: 259-273, 2007.

23. AzzamDJ,ZhaoD, Sun J,Minn AJ,RanganathanP,Drews-ElgerK, Han X, Picon-Ruiz M, Gilbert CA, Wander SA, et al: Triple negative breast cancer initiating cell subsets differ in functional and molecular characteristics and in $\gamma$-secretase inhibitor drug responses. EMBO Mol Med 5: 1502-1522, 2013.

24. Chakrabarti R, Wei Y, Romano RA, DeCoste C, Kang Y and Sinha S: Elf5 regulates mammary gland stem/progenitor cell fate by influencing notch signaling. Stem Cells 30: 1496-1508, 2012.

25. Li L, Guturi KKN, Gautreau B, Patel PS, Saad A, Morii M, Mateo F, Palomero L, Barbour H, Gomez A, et al: Ubiquitin ligase RNF8 suppresses Notch signaling to regulate mammary development and tumorigenesis. J Clin Invest 128: 4525-4542, 2018.

26. Kouros-Mehr H, Bechis SK, Slorach EM, Littlepage LE, Egeblad M, Ewald AJ, Pai SY, Ho IC and Werb Z: GATA-3 links tumor differentiation and dissemination in a luminal breast cancer model. Cancer Cell 13: 141-152, 2008.

27. Chakrabarti R, Hwang J, Andres Blanco M, Wei Y, Lukačišin M, Romano RA, Smalley K, Liu S, Yang Q, Ibrahim T, et al: Elf5 inhibits epithelial mesenchymal transition in mammary gland development and breast cancer metastasis by transcriptionally repressing Snail2. Nat Cell Biol 14: 1212-1222, 2012.

28. Lin HY, Liang YK, Dou XW, Chen CF, Wei XL, Zeng, Bai JW, Guo YX, Lin FF, Huang WH, et al: Notch3 inhibits epithelial-mesenchymal transition in breast cancer via a novel mechanism, upregulation of GATA-3 expression. Oncogenesis 7: 59, 2018.

29. Mack GS and Marshall A: Lost in migration. Nat Biotechnol 28: 214-229, 2010.

30. Liu X, Li J, Cadilha BL, Markota A, Voigt C, Huang Z, Lin PP, Wang DD, Dai J, Kranz G, et al: Epithelial-type systemic breast carcinoma cells with a restricted mesenchymal transition are a major source of metastasis. Sci Adv 5: eaav4275, 2019.

31. Shao S, Zhao X, Zhang X, Luo M, Zuo X, Huang S, Wang Y, $\mathrm{Gu} S$ and Zhao $X$ : Notch1 signaling regulates the epithelial-mesenchymal transition and invasion of breast cancer in a Slug-dependent manner. Mol Cancer 14: 28, 2015.

32. Leong KG, Niessen K, Kulic I, Raouf A, Eaves C, Pollet I and Karsan A: Jagged1-mediated Notch activation induces epithelial-to-mesenchymal transition through Slug-induced repression of E-cadherin. J Exp Med 204: 2935-2948, 2007.

33. Chen J, Imanaka N, Chen J and Griffin JD: Hypoxia potentiates Notch signaling in breast cancer leading to decreased E-cadherin expression and increased cell migration and invasion. $\mathrm{Br}$ J Cancer 102: 351-360, 2010. 
34. Jian J, Yang Q, Shao Y, Axelrod D, Smith J, Singh B, Krauter S, Chiriboga L, Yang Z, Li J and Huang X: A link between premenopausal iron deficiency and breast cancer malignancy. BMC Cancer 13: 307, 2013.

35. Liu L, Chen X, Wang Y, Qu Z, Lu Q, Zhao J, Yan X, Zhang H and Zhou Y: Notch3 is important for TGF- $\beta$-induced epithelial-mesenchymal transition in non-small cell lung cancer bone metastasis by regulating ZEB-1. Cancer Gene Ther 21: 364-372, 2014.

36. Bolos V, Mira E, Martinez-Poveda B, Luxán G, Cañamero M Martínez-A C, Mañes S and de la Pompa JL: Notch activation stimulates migration of breast cancer cells and promotes tumor growth. Breast Cancer Res 15: R54, 2013.

37. Brabletz S, Bajdak K, Meidhof S, Burk U, Niedermann G, Firat E, Wellner U, Dimmler A, Faller G, Schubert J and Brabletz T: The ZEB1/miR-200 feedback loop controls Notch signalling in cancer cells. EMBO J 30: 770-782, 2011.

38. Zhang X, Zhao X, Shao S, Zuo X, Ning Q, Luo M, Gu S and Zhao X: Notch1 induces epithelial-mesenchymal transition and the cancer stem cell phenotype in breast cancer cells and STAT3 plays a key role. Int J Oncol 46: 1141-1148, 2015.

39. Kim RK, Kaushik N, Suh Y, Yoo KC, Cui YH, Kim MJ, Lee HJ Kim IG and Lee SJ: Radiation driven epithelial-mesenchymal transition is mediated by Notch signaling in breast cancer. Oncotarget 7: 53430-53442, 2016.

40. Jin S, Mutvei AP, Chivukula IV, Andersson ER, Ramsköld D, Sandberg R, Lee KL, Kronqvist P, Mamaeva V, Ostling P, et al: Non-canonical Notch signaling activates IL-6/JAK/STAT signaling in breast tumor cells and is controlled by p53 and IKK $\alpha /$ IKK $\beta$. Oncogene 32: 4892-4902, 2013.

41. Zhang J, Shao X, Sun H, Liu K, Ding Z, Chen J, Fang L, Su W, Hong Y, Li H and Li H: NUMB negatively regulates the epithelial-mesenchymal transition of triple-negative breast cancer by antagonizing Notch signaling. Oncotarget 7: 61036-61053, 2016.

42. Garcia-Heredia JM, Verdugo Sivianes EM, Lucena-Cacace A, Molina-Pinelo S and Carnero A: Numb-like (NumbL) downregulation increases tumorigenicity, cancer stem cell-like properties and resistance to chemotherapy. Oncotarget 7: 63611-63628, 2016.

43. Wang $\mathrm{J}, \mathrm{Fu} \mathrm{L}, \mathrm{Gu} F$ and Ma Y: Notch1 is involved in migration and invasion of human breast cancer cells. Oncol Rep 26 1295-1303, 2011

44. Dou XW, Liang YK, Lin HY, Wei XL, Zhang YQ, Bai JW, Chen CF, Chen M, Du CW, Li YC, et al: Notch3 maintains luminal phenotype and suppresses tumorigenesis and metastasis of breast cancer via trans-activating estrogen receptor-alpha. Theranostics 7: 4041-4056, 2017.

45. Kessenbrock K, Plaks V and Werb Z: Matrix metalloproteinases: Regulators of the tumor microenvironment. Cell 141: 52-67, 2010

46. Li L, Zhao F, Lu J, Li T, Yang H, Wu C and Liu Y: Notch-1 signaling promotes the malignant features of human breast cancer through NF-kB activation. PLoS One 9: e95912, 2014.

47. Mahmood N, Mihalcioiu C and Rabbani SA: Multifaceted role of the urokinase-type plasminogen activator (uPA) and its receptor (uPAR): Diagnostic, Prognostic, and therapeutic applications. Front Oncol 8: 24, 2018

48. Heiss MM, Allgayer H, Gruetzner KU, Funke I, Babic R, Jauch KW and Schildberg FW: Individual development and uPA-receptor expression of disseminated tumour cells in bone marrow: A reference to early systemic disease in solid cancer. Nat Med 1: 1035-1039, 1995.

49. Shimizu M, Cohen B, Goldvasser P, Berman H, Virtanen C and Reedijk M: Plasminogen activator uPA is a direct transcriptional target of the JAG1-Notch receptor signaling pathway in breast cancer. Cancer Res 71: 277-286, 2011.

50. Song J: Notch signaling mediates Tumor-CAF crosstalk in basal-like breast cancer, 2014.

51. Liu ZJ, Lsemenza G and Zhang HF: Hypoxia-inducible factor 1 and breast cancer metastasis. J Zhejiang Univ Sci B 16: 32-43, 2015.

52. Gupta GP and Massagué J: Cancer metastasis: Building a framework. Cell 127: 679-695, 2006.

53. Semenza GL: HIF-1 and tumor progression: Pathophysiology and therapeutics. Trends Mol Med 8 (Suppl 4): S62-S67, 2002.

54. Harris AL: Hypoxia-a key regulatory factor in tumour growth Nat Rev Cancer 2: 38-47, 2002.

55. De EF, Maggiolini M and Musti AM: Crosstalk between Notch, HIF-1 $\alpha$ and GPER in Breast Cancer EMT. Int J Mol Sci 19: 2011, 2018.
56. Lim SO, Kim HS, Quan X, Ahn SM, Kim H, Hsieh D, Seong JK and Jung G: Notch1 binds and induces degradation of Snail in hepatocellular carcinoma. BMC Biol 9: 83, 2011.

57. Boufraqech M, Zhang L, Nilubol N, Sadowski SM, Kotian S, Quezado M and Kebebew E: Lysyl Oxidase (LOX) Transcriptionally Regulates SNAI2 Expression and TIMP4 Secretion in Human Cancers. Clin Cancer Res 22: 4491-4504, 2016.

58. Sahlgren C, Gustafsson MV, Jin S, Poellinger L and Lendahl U: Notch signaling mediates hypoxia-induced tumor cell migration and invasion. Proc Natl Acad Sci USA 105: 6392-6397, 2008.

59. Villanueva MT: Metastasis: LOX does some prepping. Nat Rev Cancer 15: 384, 2015.

60. Deshmukh SK, Srivastava SK, Tyagi N, Ahmad A, Singh AP, Ghadhban AAL, Dyess DL, Carter JE, Dugger K and Singh S: Emerging evidence for the role of differential tumor microenvironment in breast cancer racial disparity: A closer look at the surroundings. Carcinogenesis 38: 757-765, 2017.

61. Aboussekhra A: Role of cancer-associated fibroblasts in breast cancer development and prognosis. Int J Dev Biol 55: 841-849, 2011.

62. Shimoda M, Principe S, Jackson HW, Luga V, Fang H, Molyneux SD, Shao YW, Aiken A, Waterhouse PD, Karamboulas C, et al: Loss of the Timp gene family is sufficient for the acquisition of the CAF-like cell state. Nat Cell Biol 16: 889-901, 2014

63. Procopio MG, Laszlo C, Al Labban D, Kim DE, Bordignon P, Jo SH, Goruppi S, Menietti E, Ostano P, Ala U, et al: Combined CSL and p53 downregulation promotes cancer-associated fibroblast activation. Nat Cell Biol 17: 1193-1204, 2015.

64. Gajewski TF, Schreiber H and Fu YX: Innate and adaptive immune cells in the tumor microenvironment. Nat Immunol 14: 1014-1022, 2013

65. Cho OH, Shin HM, Miele L, Golde TE, Fauq A, Minter LM and Osborne BA: Notch regulates cytolytic effector function in CD8+ T cells. J Immunol 182: 3380-3389, 2009.

66. Qiu H, Zmina PM, Huang AY, Askew D and Bedogni B: Inhibiting Notch1 enhances immunotherapy efficacy in melanoma by preventing Notch1 dependent immune suppressive properties. Cancer Lett 434: 144-151, 2018

67. Sugimoto K, Maekawa Y, Kitamura A, Nishida J, Koyanagi A, Yagita H, Kojima H, Chiba S, Shimada M and Yasutomo K: Notch2 signaling is required for potent antitumor immunity in vivo. J Immunol 184: 4673-4678, 2010.

68. Palaga T, Wongchana W and Kueanjinda P: Notch signaling in macrophages in the context of cancer immunity. Front Immunol 9: 652, 2018.

69. Franklin RA, Liao W, Sarkar A, Kim MV, Bivona MR, Liu K, Pamer EG and Li MO: The cellular and molecular origin of tumor-associated macrophages. Science 344: 921-925, 2014.

70. Zhao JL, Huang F, He F, Gao CC, Liang SQ, Ma PF, Dong GY, Han $\mathrm{H}$ and Qin HY: Forced activation of notch in macrophages represses tumor growth by upregulating miR-125a and disabling tumor-associated macrophages. Cancer Res 76: 1403-1415, 2016.

71. Hanahan D and Folkman J: Patterns and emerging mechanisms of the angiogenic switch during tumorigenesis. Cell 86: 353-364, 1996.

72. Zhou Z, Yao $\mathrm{H}$ and $\mathrm{Hu} \mathrm{H}$ : Disrupting Tumor Angiogenesis and 'the Hunger Games' for Breast Cancer. Adv Exp Med Biol 1026: 171,2017

73. Zetter BR: Angiogenesis and tumor metastasis. Annu Rev Med 49: 407-424, 1998

74. Cuervo H, Nielsen CM, Simonetto DA, Ferrell L, Shah VH and Wang RA: Endothelial notch signaling is essential to prevent hepatic vascular malformations in mice. Hepatology 64: 1302-1316, 2016.

75. Kontomanolis EN, Kalagasidou S, Pouliliou S, Anthoulaki X, Georgiou N,Papamanolis V andFasoulakisZN: The notch pathway in breast cancer progression. ScientificWorldJournal 2018: 2415489, 2018

76. Blanco R and Gerhardt H: VEGF and Notch in tip and stalk cell selection. Cold Spring Harb Perspect Med 3: a006569, 2013.

77. Siekmann AF, Covassin L and Lawson ND: Modulation of VEGF signalling output by the Notch pathway. Bioessays 30: 303-313, 2008

78. Mailhos C, Modlich U, Lewis J, Harris A, Bicknell R and Ish-Horowicz D: Delta4, an endothelial specific notch ligand expressed at sites of physiological and tumor angiogenesis. Differentiation 69: 135-144, 2001. 
79. Hellstrom M, Phng LK, Hofmann JJ, Wallgard E, Coultas L, Lindblom P, Alva J, Nilsson AK, Karlsson L, Gaiano N, et al: Dl14 signalling through Notch1 regulates formation of tip cells during angiogenesis. Nature 445: 776-780, 2007.

80. Suchting S and Eichmann A: Jagged gives endothelial tip cells an edge. Cell 137: 988-990, 2009.

81. Phng LK and Gerhardt H: Angiogenesis: A team effort coordinated by notch. Dev Cell 16: 196-208, 2009.

82. Oon CE, Li JL, Sainson R, Sheldon H, Turley H, Leek R and Harris A: 360 Role of DLL4 and JAG1 in tumour angiogenesis. EJC Supplements 8: 92-92, 2010.

83. Panin VM, Papayannopoulos V, Wilson R and Irvine KD: Fringe modulates Notch-ligand interactions. Nature 387: 908-912, 1997.

84. Boareto M, Jolly MK, Ben-Jacob E and Onuchic JN: Jagged mediates differences in normal and tumor angiogenesis by affecting tip-stalk fate decision. Proc Natl Acad Sci USA 112: E3836-E3844, 2015.

85. Benedito R, Roca C, Sörensen I, Adams S, Gossler A, Fruttiger M and Adams RH: The Notch Ligands Dll4 and Jagged1 have opposing effects on Angiogenesis. Cell 137: 1124-1135, 2009.

86. Chen JY, Li CF, Chu PY, Lai YS, Chen CH, Jiang SS, Hou MF and Hung WC: Lysine demethylase 2A promotes stemness and angiogenesis of breast cancer by upregulating Jagged1. Oncotarget 7: 27689-27710, 2016

87. Rodriguez-Vita $\mathbf{J}$ and Fischer A: Notch signaling facilitates crossing of endothelial barriers by tumor cells. Mol Cell Oncol 4: e1311828, 2017.

88. White DE and Muller WJ: Multifaceted Roles of integrins in breast cancer metastasis. J Mammary Gland Biol Neoplasia 12: 135-142, 2007.

89. Deford P, Brown K, Richards RL, King A, Newburn K, Westover K and Albig AR: MAGP2 controls Notch via interactions with RGD binding integrins: Identification of a novel ECM-integrin-Notch signaling axis. Exp Cell Res 341: 84-91, 2016.

90. Hodkinson PS, Elliott PA, Lad Y, McHugh BJ, MacKinnon AC, Haslett $\mathrm{C}$ and Sethi T: Mammalian NOTCH-1 activates beta1 integrins via the small GTPase R-Ras. J Biol Chem 282: 28991-29001, 2007

91. Liu B, Zheng X, Meng F, Han Y, Song Y, Liu F, Li S, Zhang L, $\mathrm{Gu} F$, Zhang X and Fu L: Overexpression of $\beta 1$ integrin contributes to polarity reversal and a poor prognosis of breast invasive micropapillary carcinoma. Oncotarget 9: 4338-4353, 2017.

92. Stoletov K, Kato H, Zardouzian E, Kelber J, Yang J, Shattil S and Klemke R: Visualizing extravasation dynamics of metastatic tumor cells. J Cell Sci 123: 2332-2341, 2010.

93. Guo P and Rafii S: Dangerous liaisons: Deviant endothelium NOTCHes toward tumor metastasis. Cancer Cell 31: 301-303, 2017.

94. Lianidou ES and Markou A: Circulating tumor cells in breast cancer: Detection systems, molecular characterization, and future challenges. Clin Chem 57: 1242-1255, 2011.

95. Boral D, Vishnoi M, Liu HN, Yin W, Sprouse ML, Scamardo A, Hong DS, Tan TZ, Thiery JP, Chang JC and Marchetti D: Molecular characterization of breast cancer CTCs associated with brain metastasis. Nat Commun 8: 196, 2017.

96. Portanova P, Notaro A, Pellerito O, Sabella S, Giuliano M and Calvaruso G: Notch inhibition restores TRAIL-mediated apoptosis via AP1-dependent upregulation of DR4 and DR5 TRAIL receptors in MDA-MB-231 breast cancer cells. Int J Oncol 43: 121-130, 2013

97. Day TW, Huang S and Safa AR: c-FLIP knockdown induces ligand-independent DR5-, FADD-, caspase-8-, and caspase-9-dependent apoptosis in breast cancer cells. Biochem Pharmacol 76: 1694-1704, 2008.

98. Kim JW, Kim MJ, Kim KJ, Yun HJ, Chae JS, Hwang SG, Chang TS, Park HS, Lee KW, Han PL, et al: Notch interferes with the scaffold function of JNK-interacting protein 1 to inhibit the JNK signaling pathway. Proc Natl Acad Sci USA 102: $14308-14313,2005$

99. Archibald A, Mihai C, Macara IG and McCaffrey L: Oncogenic suppression of apoptosis uncovers a Rac1/JNK proliferation pathway activated by loss of Par3. Oncogene 34: 3199-3206, 2015

100.Zou W, Liu X, Yue P, Zhou Z, Sporn MB, Lotan R, Khuri FR and Sun SY: c-Jun NH2-terminal kinase-mediated up-regulation of death receptor 5 contributes to induction of apoptosis by the novel synthetic triterpenoid methyl-2-cyano-3,12-dioxooleana-1, 9-dien-28-oate in human lung cancer cells. Cancer Res 64: $7570-7578,2004$
101. Naik S, MacFarlane M and Sarin A: Notch4 signaling confers susceptibility to TRAIL-Induced Apoptosis in breast cancer cells. J Cell Biochem 116: 1371-1380, 2015.

102. Phipps LE, Hino S and Muschel RJ: Targeting cell spreading: A method of sensitizing metastatic tumor cells to TRAIL-induced apoptosis. Mol Cancer Res 9: 249-258, 2011.

103. Meurette O, Stylianou S, Rock R, Collu GM, Gilmore AP and Brennan K: Notch activation induces Akt signaling via an autocrine loop to prevent apoptosis in breast epithelial cells. Cancer Res 69: 5015-5022, 2009.

104. Tao L, Roberts AL, Dunphy KA, Bigelow C, Yan H and Jerry DJ: Repression of mammary stem/progenitor cells by p53 is mediated by Notch and separable from apoptotic activity. Stem Cells 29: 119-127, 2011.

105. Su F, Zhu S, Ruan J, Muftuoglu Y, Zhang L and Yuan Q: Combination therapy of RY10-4 with the gamma-secretase inhibitor DAPT shows promise in treating HER2-amplified breast cancer. Oncotarget 7: 4142-4154, 2016.

106. Hay N: The Akt-mTOR tango and its relevance to cancer. Cancer Cell 8: 179-183, 2005.

107. Li L, Zhang J, Xiong N, Li S, Chen Y, Yang H, Wu C, Zeng H and Liu Y: Notch-1 signaling activates NF- $\mathrm{B}$ in human breast carcinoma MDA-MB-231 cells via PP2A-dependent AKT pathway. Med Oncol 33: 33, 2016.

108. Guerrero-Zotano A, Mayer IA and Arteaga CL: $\mathrm{PI} 3 \mathrm{~K} / \mathrm{AKT} / \mathrm{mTOR}$ : Role in breast cancer progression, drug resistance, and treatment. Cancer Metastasis Rev 35: 515-524, 2016.

109. Mungamuri SK, Yang X, Thor AD and Somasundaram K: Survival signaling by Notch1: Mammalian target of rapamycin (mTOR)-dependent inhibition of p53. Cancer Res 66: 4715-4724, 2006.

110. Dotto GP: Crosstalk of Notch with p53 and p63 in cancer growth control. Nat Rev Cancer 9: 587-595, 2009.

111. Kim SB, Chae GW, Lee J, Park J, Tak H, Chung JH, Park TG, Ahn JK and Joe CO: Activated Notch1 interacts with p53 to inhibit its phosphorylation and transactivation. Cell Death Differ 14: 982-991, 2007.

112. Cherdyntseva NV, Litviakov NV, Denisov EV, Gervas PA and Cherdyntsev ES: Circulating tumor cells in breast cancer: Functional heterogeneity, pathogenetic and clinical aspects. Exp Oncol 39: 2-11, 2017

113. Zhang P, He D, Chen Z, Pan Q, Du F, Zang X, Wang Y, Tang C, $\mathrm{Li} \mathrm{H}, \mathrm{Lu} \mathrm{H}$, et al: Chemotherapy enhances tumor vascularization via Notch signaling-mediated formation of tumor-derived endothelium in breast cancer. Biochem Pharmacol 118: 18-30, 2016.

114. Simões BM, O'Brien CS, Eyre R, Silva A, Yu L, Sarmiento-Castro A, Alférez DG, Spence K, Santiago-Gómez A, Chemi F, et al: Anti-estrogen resistance in human breast tumors is driven by JAG1-NOTCH4-Dependent cancer stem cell activity. Cell Rep 12: 1968-1977, 2015.

115. Sansone P, Ceccarelli C, Berishaj M, Chang Q, Rajasekhar VK, Perna F, Bowman RL, Vidone M, Daly L, Nnoli J, et al: Self-renewal of CD133(hi) cells by IL6/Notch3 signalling regulates endocrine resistance in metastatic breast cancer. Nat Commun 7: 10442, 2016.

116. Boelens MC, Wu TJ, Nabet BY, Xu B, Qiu Y, Yoon T, Azzam DJ, Twyman-Saint Victor C, Wiemann BZ, Ishwaran $\mathrm{H}$, et al: Exosome transfer from stromal to breast cancer cells regulates therapy resistance pathways. Cell 159: 499-513, 2014.

117. Arteaga CL and Engelman JA: ERBB receptors: From oncogene discovery to basic science to mechanism-based cancer therapeutics. Cancer Cell 25: 282-303, 2014.

118. Jordan NV, Bardia A, Wittner BS, Benes C, Ligorio M, Zheng Y, Yu M, Sundaresan TK, Licausi JA, Desai R, et al: HER2 expression identifies dynamic functional states within circulating breast cancer cells. Nature 537: 102-106, 2016.

119. Kang Y: Dissecting Tumor-Stromal interactions in breast cancer bone metastasis. Endocrinol Metab (Seoul) 31: 206-212, 2016.

120. Zhang Z, Wang H, Ikeda S, Fahey F, Bielenberg D, Smits P and Hauschka PV: Notch3 in human breast cancer cell lines regulates osteoblast-cancer cell interactions and osteolytic bone metastasis. Am J Pathol 177: 1459-1469, 2010.

121. Sethi N, Dai X, Winter CG and Kang Y: Tumor-derived JAGGED1 promotes osteolytic bone metastasis of breast cancer by engaging notch signaling in bone cells. Cancer Cell 19: $192-205,2011$.

122. Lee JH and Welch DR: Suppression of metastasis in human breast carcinoma MDA-MB-435 cells after transfection with the metastasis suppressor gene, KiSS-1. Cancer Res 57: 2384-2387, 1997. 
123. Ohtaki T, Shintani Y, Honda S, Matsumoto H, Hori A, Kanehashi K, Terao Y, Kumano S, Takatsu Y, Masuda Y, et al: Metastasis suppressor gene KiSS-1 encodes peptide ligand of a G-protein-coupled receptor. Nature 411: 613-617, 2001.

124. Leone A, Flatow U, Vanhoutte K and Steeg PS: Transfection of human nm23-H1 into the human MDA-MB-435 breast carcinoma cell line: Effects on tumor metastatic potential, colonization and enzymatic activity. Oncogene 8: 2325-2333, 1993.

125. Yu HG, Huang JA, Yang YN, Huang H, Luo HS, Yu JP, Meier JJ, Schrader H, Bastian A, Schmidt WE and Schmitz F: The effects of acetylsalicylic acid on proliferation, apoptosis, and invasion of cyclooxygenase- 2 negative colon cancer cells. Eur J Clin Invest 32: 838-846, 2002.

126. Moon CM, Kwon JH, Kim JS, Oh SH, Jin Lee K, Park JJ, Pil Hong S, Cheon JH, Kim TI and Kim WH: Nonsteroidal anti-inflammatory drugs suppress cancer stem cells via inhibiting PTGS2 (cyclooxygenase 2) and NOTCH/HES1 and activating PPARG in colorectal cancer. Int J Cancer 134: 519-529, 2014

127. Ignesti M, Barraco M, Nallamothu G, Woolworth JA, Duchi S, Gargiulo G, Cavaliere V and Hsu T: Notch signaling during development requires the function of awd, the Drosophila homolog of human metastasis suppressor gene Nm23. BMC Biol 12: 12, 2014.

128. Oskarsson T, Acharyya S, Zhang XH, Vanharanta S, Tavazoie SF, Morris PG, Downey RJ, Manova-Todorova K, Brogi $\mathrm{E}$ and Massagué J: Breast cancer cells produce tenascin $\mathrm{C}$ as a metastatic niche component to colonize the lungs. Nat Med 17: 867-874, 2011

129. Wang XY, Penalva LO, Yuan H, Linnoila RI, Lu J, Okano H and Glazer RI: Musashi1 regulates breast tumor cell proliferation and is a prognostic indicator of poor survival. Mol Cancer 9: 221,2010 .

130. Reedijk M, Odorcic S, Chang L, Zhang H, Miller N, McCready DR, Lockwood G and Egan SE: High-level coexpression of JAG1 and NOTCH1 is observed in human breast cancer and is associated with poor overall survival. Cancer Res 65: 8530-8537, 2005.

131. Tanabe H, Takayama I, Nishiyama T, Shimazaki M, Kii I, Li M, Amizuka N, Katsube K and Kudo A: Periostin associates with Notch1 precursor to maintain Notch1 expression under a stress condition in mouse cells. PLoS One 5: e12234, 2010.

132. Zhou M, Kawashima N, Suzuk N, Yamamoto M, Ohnishi K, Katsube K, Tanabe H, Kudo A, Saito M and Suda H: Periostin is a negative regulator of mineralization in the dental pulp tissue. Odontology 103: 152-159, 2015.

133. Kii I, Nishiyama T, Li M, Matsumoto K, Saito M, Amizuka N and Kudo A: Incorporation of tenascin-C into the extracellular matrix by periostin underlies an extracellular meshwork architecture. J Biol Chem 285: 2028-2039, 2010.

134. Aguirre-Ghiso JA: Models, mechanisms and clinical evidence for cancer dormancy. Nat Rev Cancer 7: 834-846, 2007.

135. Aguirre Ghiso JA, Kovalski K and Ossowski L: Tumor dormancy induced by downregulation of urokinase receptor in human carcinoma involves integrin and MAPK signaling. J Cell Biol 147: 89-104, 1999.

136. Masiero M, Minuzzo S, Pusceddu I, Moserle L, Persano L, Agnusdei V, Tosello V, Basso G, Amadori A and Indraccolo S: Notch3-mediated regulation of MKP-1 levels promotes survival of T acute lymphoblastic leukemia cells. Leukemia 25: 588-598, 2011.

137. Enderling H, Almog N and Hlatky L: Systems biology of tumor dormancy. Springer New York, 2013.

138. Zhang Y, Li J, Lai XN, Jiao XQ, Xiong JP and Xiong LX: Focus on Cdc42 in Breast Cancer: New insights, target therapy development and non-coding RNAs. Cells 8: pii: E146, 2019.

139. Ors-Kumoglu G, Gulce-Iz S and Biray-Avci C: Therapeutic microRNAs in human cancer. Cytotechnology 71: 411-425, 2019.

140. Hayes J, Peruzzi PP and Lawler S: MicroRNAs in cancer: Biomarkers, functions and therapy. Trends Mol Med 20: 460-469, 2014.

141. Wu MY, Fu J, Xiao X, Wu J and Wu RC: MiR-34a regulates therapy resistance by targeting HDAC1 and HDAC7 in breast cancer. Cancer Lett 354: 311-319, 2014

142. Li XJ, Ji MH, Zhong SL, Zha QB, Xu JJ, Zhao JH and Tang JH: MicroRNA-34a modulates chemosensitivity of breast cancer cells to adriamycin by targeting Notch1. Arch Med Res 43: 514-521, 2012

143. Rui X,Zhao H, Xiao X, Wang L, Mo L and Yao Y: MicroRNA-34a suppresses breast cancer cell proliferation and invasion by targeting Notch1. Exp Ther Med 16: 4387-4392, 2018.
144. Lan L, Wang Y, Pan Z, Wang B, Yue Z, Jiang Z, Li L, Wang C and Tang $H$ : Rhamnetin induces apoptosis in human breast cancer cells via the miR-34a/Notch-1 signaling pathway. Oncol Lett 17: 676-682, 2019.

145. Kang L, Mao J, Tao Y, Song B, Ma W, Lu Y, Zhao L, Li J, Yang B and Li L: MiR-34a suppresses the breast cancer stem cell-like characteristics by downregulating Notch1 pathway. Cancer Sci 106: 700-708, 2015.

146. Park EY, Chang E, Lee EJ, Lee HW, Kang HG, Chun KH, Woo YM, Kong HK, Ko JY, Suzuki H, et al: Targeting of miR34a-NOTCH1 axis reduced breast cancer stemness and chemoresistance. Cancer Res 74: 7573-7582, 2014.

147. Suman S, Das TP and Damodaran C: Silencing NOTCH signaling causes growth arrest in both breast cancer stem cells and breast cancer cells. Br J Cancer 109: 2587-2596, 2013.

148. Heller G, Altenberger C, Steiner I, Topakian T, Ziegler B, Tomasich E, Lang G, End-Pfützenreuter A, Zehetmayer S, Döme B, et al: DNA methylation of microRNA-coding genes in non-small-cell lung cancer patients. J Pathol 245: 387-398, 2018.

149. Li WJ, Xie XX, Bai J, Wang C, Zhao L and Jiang DQ: Increased expression of miR-1179 inhibits breast cancer cell metastasis by modulating Notch signaling pathway and correlates with favorable prognosis. Eur Rev Med Pharmacol Sci 22: 8374-8382, 2018.

150. Kong P, Chen L, Yu M, Tao J, Liu J, Wang Y, Pan H, Zhou W and Wang S: miR-3178 inhibits cell proliferation and metastasis by targeting Notch1 in triple-negative breast cancer. Cell Death Dis 9: 1059, 2018

151. Mohammadi-Yeganeh S, Mansouri A and Paryan M: Targeting of miR9/NOTCH1 interaction reduces metastatic behavior in triple-negative breast cancer. Chem Biol Drug Des 86: 1185-1191, 2015

152. Liang YK, Lin HY, Dou XW, Chen M, Wei XL, Zhang YQ, Wu Y, Chen CF, Bai JW, Xiao YS, et al: MiR-221/222 promote epithelial-mesenchymal transition by targeting Notch3 in breast cancer cell lines. NPJ Breast Cancer 4: 20, 2018.

153. Forloni M, Dogra SK, Dong Y, Conte D Jr, Ou J, Zhu LJ, Deng A, Mahalingam M, Green MR and Wajapeyee N: miR-146a promotes the initiation and progression of melanoma by activating Notch signaling. Elife 3: e01460, 2014.

154. Kuang W, Tan J, Duan Y, Duan J, Wang W, Jin F, Jin Z, Yuan X and Liu Y: Cyclic stretch induced miR-146a upregulation delays C2C12 myogenic differentiation through inhibition of Numb. Biochem Biophys Res Commun 378: 259-263, 2009.

155. Marino N, Woditschka S, Reed LT, Nakayama J, Mayer M, Wetzel M and Steeg PS: Breast cancer metastasis: Issues for the personalization of its prevention and treatment. Am J Pathol 183: 1084-1095, 2013.

156. Locatelli MA, Aftimos P, Dees EC, LoRusso PM, Pegram MD, Awada A, Huang B, Cesari R, Jiang Y, Shaik MN, et al: Phase I study of the gamma secretase inhibitor PF-03084014 in combination with docetaxel in patients with advanced triple-negative breast cancer. Oncotarget 8: 2320-2328, 2017.

157. Piha-Paul SA, Munster PN, Hollebecque A, Argilés G, Dajani O, Cheng JD, Wang R, Swift A, Tosolini A and Gupta S: Results of a phase 1 trial combining ridaforolimus and MK-0752 in patients with advanced solid tumours. Eur J Cancer 51: 1865-1873, 2015.

158. Takebe N, Nguyen D and Yang SX: Targeting notch signaling pathway in cancer: Clinical development advances and challenges. Pharmacol Ther 141: 140-149, 2014.

159. So JY, Wahler J, Das Gupta S, Salerno DM, Maehr H, Uskokovic M and Suh N: HES1-mediated inhibition of Notch1 signaling by a Gemini vitamin D analog leads to decreased $\mathrm{CD} 44^{+} / \mathrm{CD} 24^{-} /$low tumor-initiating subpopulation in basal-like breast cancer. J Steroid Biochem Mol Biol 148: 111-121, 2015.

160. Krop IE, Kosh M, Fearen I, Savoie JG, Dallob AL, Matthews CK, Stone J, Winer EP, Freedman SJ and LoRusso PM: Phase I pharmacokinetic (PK), and pharmacodynamic (PD) trial of the novel oral Notch inhibitor MK-0752 in patients (pts) with advanced breast cancer (BC) and other solid tumors. Ann Oncol 22: 1413-1419, 2006.

161. Locatelli M and Curigliano G: Notch inhibitors and their role in the treatment of triple negative breast cancer: Promises and failures. Curr Opin Oncol 29: 411-427, 2017.

162. Sanchez L, Muchene L, Lorenzo-Luaces P, Viada C, Rodriguez PC, Alfonso S, Crombet T, Neninger E, Shkedy Z and Lage A: Differential effects of two therapeutic cancer vaccines on short- and long-term survival populations among patients with advanced lung cancer. Semin Oncol 45: 52-57, 2018. 
163. Makhoul I, Atiq M, Alwbari A and Kieber-Emmons T: Breast cancer immunotherapy: Anupdate. Breast Cancer(Auckl): May30, 2018 (Epud ahead of print). doi: 10.1177/1178223418774802.

164. Gu X, Lu C, He D, Lu Y, Jin J, Liu D and Ma X: Notch3 negatively regulates chemoresistance in breast cancers. Tumour Biol: Oct 14, 2016 (Epub ahead of print).

165. Lu X and Kang Y: Efficient acquisition of dual metastasis organotropism to bone and lung through stable spontaneous fusion between MDA-MB-231 variants. Proc Natl Acad Sci USA 106: 9385-9390, 2009.

166. Colombo M, Raposo G and Thery C: Biogenesis, secretion, and intercellular interactions of exosomes and other extracellular vesicles. Annu Rev Cell Dev Biol 30: 255-289, 2014.

167. Hoshino A, Costa-Silva B, Shen TL, Rodrigues G, Hashimoto A, Tesic Mark M, Molina H, Kohsaka S, Di Giannatale A, Ceder S, et al: Tumour exosome integrins determine organotropic metastasis. Nature 527: 329-335, 2015.
168. Lowry MC, Gallagher WM and O'Driscoll L: The role of exosomes in breast cancer. Clin Chem 61: 1457-1465, 2015.

169. Schreck KC, Taylor P, Marchionni L, Gopalakrishnan V, Bar EE, Gaiano N and Eberhart CG: The Notch target Hes1 directly modulates Gli1 expression and Hedgehog signaling: A potential mechanism of therapeutic resistance. Clin Cancer Res 16: 6060-6070, 2010.

170. Hanna A, Metge BJ, Bailey SK, Chen D, Chandrashekar DS, Varambally S, Samant RS and Shevde LA: Inhibition of Hedgehog signaling reprograms the dysfunctional immune microenvironment in breast cancer. Oncoimmunology 8: 1548241, 2018.

(i) (9) This work is licensed under a Creative Commons Attribution-NonCommercial-NoDerivatives 4.0 International (CC BY-NC-ND 4.0) License. 